\title{
Laparoscopy Training Courses in Urology
}

\author{
Sutchin R Patel and Stephen Y Nakada \\ Department of Urology, \\ University of Wisconsin School of Medicine and Public Health \\ United States
}

\section{Introduction}

The history of laparoscopic surgery began with man's attempts to inspect concealed areas of the body. Early endoscopy from Bozzini's "lichtleiter" in 1805 to the development of modern cystoscopy by Nitze in the late 1800s helped develop the optical tools required for laparoscopy. The early 1900s saw the birth of laparoscopy with Kelling, a surgeon from Dresden, describing the technique of celioscopy in dogs and Jacobaeus from Sweden reporting two cases of thoraco-laparoscopy in which he used a trocar to create pneumoperitoneum in humans and then inserted a cystoscope. Kurt Semm, an engineer and gynecologist helped develop many of the other tools associated with laparoscopy including an automatic insufflation device that monitored gas flow and intra-abdominal pressure, thermocoagulation for use during the procedure as well as many early laparoscopy instruments. (Gomella \& Strup, 1994)

The first laparoscopic nephrectomy was performed by Clayman and colleagues in 1990. (Clayman et al., 1991) With improvements and refinement of the technology, the first laparoscopic living donor nephrectomy soon followed. (Ratner et al., 1995) In 1997, Nakada and colleagues, performed the first hand-assisted laparoscopic nephrectomy (HALN) with a sleeve in the United States. (Nakada et al., 1997) By placing a hand in the abdomen, the HALN provided urologists tactile sensation and helped decrease the learning curve for laparoscopy. (Gaston KE et al., 2004) The hand-assisted approach also allowed older urologists that had not been trained in laparoscopy to begin to perform laparoscopic cases and helped bridge the gap from open surgery and a pure laparoscopic approach. (Munver $\mathrm{R}$ et al., 2004)

With the rapid advances in technology in the field of urology, post-graduate training courses are important to help bridge the technology gap for current practicing urologists. The development of newer high-fidelity simulators and metrics for assessing laparoscopic skill acquisition are essential in order for us to better teach laparoscopic surgery.

\section{The learning curve for laparoscopy}

The application of any new technology is associated with a learning curve. In laparoscopy, the ability to translate a 2-dimensional perspective on the monitor into 3-dimensional movements inside the body, the loss of tactile sensation, the limitations of using fixed port sites which limit mobility (limited degrees of freedom: yaw, pitch, roll, insertion plus 
actuation of the instrument) and the fulcrum effect make the transition from open surgery to laparoscopy challenging. (Kumar \& Gill, 2006) Despite these shortcomings, some of the limitations can be overcome with compensatory mechanisms such as motion parallax to estimate depth and frequently touching objects in the visual field to obtain some tactile input.

Figert et al. found that a specific set of laparoscopic skills may not aid the transfer of training to a different set of laparoscopic skills and that open surgical experience does not improve the transfer of training to acquiring new laparoscopic skills. (Figert et al, 2001) They concluded that specific minimally invasive training is needed to develop laparoscopic surgery skills.

There is evidence to suggest that intensive training in the setting of a formal fellowship decreases the learning curve for laparoscopy. Cadeddu and colleagues identified no difference in the complication rates between the initial 20 to 40 laparoscopic cases compared to subsequent cases for 13 surgeons that had completed at least 1 year of fellowship training in laparoscopic surgery. (Cadeddu et al., 2001) The authors also found no change in the open conversion rate with time and concluded that the experience acquired during intensive laparoscopic training may decrease the learning curve needed to achieve proficiency.

Though the learning curve for laparoscopic surgery remains less well defined and may be different for individual surgeons and different procedures, a number of different studies have tried to estimate the learning curve for laparoscopic radical nephrectomy, donor nephrectomy and prostatectomy. (Table 1.) Phillips et al. studied a single center's learning curve for laparoscopic retroperitoneal radical nephrectomy. (Phillips et al., 2005) There was a significant difference in the operative time for the last 30 cases compared to all cases in the series. There was no significant difference between blood loss, conversion rate or complication rate between the last 30 cases compared to all cases. The authors did show a decrease in conversion to open surgery from 4 cases to 2 cases when comparing cases 1-20 to cases 21-40 but did not comment on how many cases constituted the learning curve for the procedure. Jeon et al. evaluated the outcomes for three novice surgeons and their first 50 laparoscopic radical nephrectomies. (Jeon et al., 2009) The authors found a significant difference in the estimated blood loss (236 vs $191 \mathrm{cc}, \mathrm{p}=0.04)$ and transfusion rate $(17.8 \%$ vs $4.8 \%, \mathrm{p}=0.02$ ) when comparing each surgeons' first 15 cases compared to their remaining 35 cases. There was a significant difference in operating time between the first 15 cases in the series compared to the last 15 cases but no significant difference in intraoperative complications or conversions to open surgery. The authors concluded that 15 cases were required for a novice surgeon to achieve competence in laparoscopic radical nephrectomy.

The laparoscopic approach for partial nephrectomy can be a challenging procedure requiring a surgeon to be experienced in general laparoscopic renal surgery as well as be facile with intracorporeal suturing in order to achieve hemostasis and reconstruction of the kidney within a reasonable warm ischemia time. Link et al. investigated a single institutional learning curve for laparoscopic partial nephrectomy. (Link et al., 2005) Linear regression analysis revealed that total operative time decreased significantly with increasing surgeon experience. Warm ischemia time increased significantly with larger tumor diameter but was not related to surgeon experience.

Hruza et al. evaluated the learning curve for three generations of surgeons that performed 2200 laparoscopic radical prostatectomies. (Hruza et al., 2010) First generation surgeons were defined as surgeons with a great deal of experience in open surgery but no laparoscopic training. Second generation surgeons were surgeons with open surgery 


\begin{tabular}{|c|c|c|c|}
\hline $\begin{array}{l}\text { Procedure- } \\
\text { Study }\end{array}$ & $\begin{array}{l}\text { No. Cases } \\
\text { (No. } \\
\text { Surgeons) }\end{array}$ & $\begin{array}{l}\text { Learning Curve } \\
\text { Parameter(s) } \\
\text { Studied }\end{array}$ & Results \\
\hline $\begin{array}{l}\text { LRN-Phillips et } \\
\text { al., } 2005\end{array}$ & $121(\mathrm{NR})$ & $\begin{array}{l}\text { OR Time, } \\
\text { Conversion Rate, } \\
\text { Intraop } \\
\text { Complications }\end{array}$ & $\begin{array}{l}\text { OR Time: All Cases=140 min; Last } 30 \\
\text { Cases }=120 \text { min ( } p=0.012 \text { ) } \\
\text { Conversion: } N=7 \text { in first } 60 \text { cases (none } \\
\text { after that) } \\
\text { Intraop Complications: } N=9 \text { in first } 60 \\
\text { cases; } N=3 \text { in last } 61 \text { cases }\end{array}$ \\
\hline $\begin{array}{l}\text { LRN-Jeon et al., } \\
2009\end{array}$ & $150(3)$ & $\begin{array}{l}\text { OR Time, } \\
\text { Conversion Rate, } \\
\text { Intraop } \\
\text { Complications }\end{array}$ & $\begin{array}{l}\text { Mean OR Time: } 188 \text { min (statistically } \\
\text { significant difference in OR time between } \\
\text { first } 15 \text { cases and last } 15 \text { cases); } \\
\text { Conversion: } N=1(2.2 \%) \text { in first } 45 \text { cases; } \\
\mathrm{N}=2(1.9 \%) \text { in remaining } 105 \text { Cases } \\
\text { Intraop Complications } \mathrm{N}=6(13.3 \%) \text { in } \\
\text { first } 45 \text { cases; } N=9(8.6 \%) \text { in remaining } 105 \\
\text { cases }\end{array}$ \\
\hline $\begin{array}{l}\text { LPN-Link et al., } \\
2005\end{array}$ & $178(1)$ & $\begin{array}{l}\text { OR Time, Warm } \\
\text { Ischemia Time }\end{array}$ & $\begin{array}{l}\text { Statistically significant decrease in OR } \\
\text { time with increasing surgeon experience. } \\
(p=0.003) \\
\text { Warm ischemia time is related to resected } \\
\text { tumor size }(p=0.005) \text { but not to surgeon } \\
\text { experience }(p=0.96) \text {. }\end{array}$ \\
\hline $\begin{array}{l}\text { LRP-Hruza et } \\
\text { al., } 2010\end{array}$ & $\begin{array}{l}2200 \\
(5 \text { surgeons } \\
\text { performed } \\
96 \% \text { of } \\
\text { cases) }\end{array}$ & $\begin{array}{l}\text { Complication } \\
\text { Free Rate }\end{array}$ & $\begin{array}{l}\text { Overall Complication Free Rate: } \\
1^{\text {st }} \text { Gen }(\text { Cases } 1-50)=54 \% \\
2^{\text {nd }} \text { Gen }(\text { Cases } 1-50)=60 \% \\
3^{\text {rd }} \text { Gen }(\text { Cases } 1-50)=61 \% \\
1^{\text {st }} \text { Gen }(\text { Cases } 201-250)=62 \% \\
2^{\text {nd }} \text { Gen }(\text { Cases } 151-200)=58 \% \\
3^{\text {rd }} \text { Gen }(\text { Cases } 201-250)=75 \%\end{array}$ \\
\hline $\begin{array}{l}\text { LRP-Secin et al., } \\
2010\end{array}$ & $8544(51)$ & $\begin{array}{l}\text { Positive Surgical } \\
\text { Margin Rate }\end{array}$ & $\begin{array}{l}\text { Positive Surgical Margin Rate: } 22 \% \\
\text { Absolute risk difference for } 10 \text { vs } 250 \\
\text { prior surgeries }=4.8 \%\end{array}$ \\
\hline
\end{tabular}

Table 1. Assessment of Learning Curves for Urologic Procedures. LRN: Laparoscopic Radical Nephrectomy; LPN: Laparoscopic Partial Nephrectomy; LRP: Laparoscopic Radical Prostatectomy; NR: Not Reported; OR: Operating Room; Intraop: Intraoperative; Gen: Generation

experience that were trained by the first generation surgeons in laparoscopy and third generation surgeons had no or limited open surgery training that were trained by both the first and second generation surgeons in laparoscopy. Though the technique for laparoscopic radical prostatectomy was not constant (first 871 patients: transperitoneal; remaining 1329 patients retroperitoneal) over the time of the study (1999-2008), the authors showed a higher complication-free rate for third generation surgeons in their first 50 cases and their last 50 cases (cases 201-250) when compared to first generation surgeons. The authors conclude that the individual learning curve for third generation surgeons was shorter when compared to 
first and second generation surgeons and this may be due to their dedicated learning program. In an international multicenter study, Secin et al. studied the learning curve for laparoscopic radical prostatectomy performed on 8,544 consecutive patients by 51 surgeons from 14 academic institutions in Europe and the United States. (Secin et al., 2010) The authors investigated the learning curve of laparoscopic radical prostatectomy for positive surgical margins and compared it to a published learning curve for open radical prostatectomy. There was an improvement in surgical margin rates up to a plateau at 200 to 250 surgeries with an absolute risk difference for 10 vs 250 prior surgeries of $4.8 \%$ (95\% CI 1.5,8.5). Neither surgeon generation nor prior open radical prostatectomy experience improved the margin rate suggesting that the positive surgical margin rate is primarily a function of laparoscopic training and experience.

The learning curve for procedures can be difficult to compare even between studies on the same procedure since results (such as operative time, conversions, intraoperative complications, blood loss or positive margin status) are not always reported and when they are reported they are not reported in quartiles or in terms of which case they occurred in the series. It is also important to realize that the learning curve for a procedure may differ for each individual surgeon. Given that many of the papers in the literature are carried out at large academic institutions, the learning curve for surgeons in community practice with limited case access may be different.

For urologists that were not trained in laparoscopy, hand-assisted laparoscopic surgery can serve as a bridge between open surgery and laparoscopy. The loss of tactile sensation is one major factor that prolongs the learning curve for laparoscopic surgery. Having a hand in the abdomen can help provide tactile sensation as well as allow an easier method to retract tissue and aid in dissection. Hand-assisted surgery thus makes it easier and safer to transition from open surgery to laparoscopy for surgeons that have not received formal training in laparoscopy. Gaston et al. demonstrated a short learning curve for hand-assisted laparoscopic radical nephrectomy via decreasing difficulty scores and operative times in as few as 4 cases. (Gaston et al., 2004) The oncologic, operative and postoperative results for hand-assisted laparoscopic radical nephrectomy have been shown to be comparable to standard laparoscopy and thus may be an advantageous approach early in a surgeon's experience or for cases involving larger tumors. (Nelson et al., 2002)

\section{Laparoscopic training courses}

With the increased prevalence of laparoscopy in urology, reliable training and assessment of skill become increasingly important. Laparoscopic skills are not an innate behavior, nor can they be easily learned by observation or through reading surgical texts and can only be acquired through hands-on training. (Emken et al., 2004) Because of the unique nature of the laparoscopic skill set, teaching these skills requires an increased emphasis on practical and skills training. (Derossis et al., 1998; Scott et al., 2001) Laparoscopy is different from open surgery in that its performed using long instruments inserted through ports made in the skin. The laparoscopic instruments can amplify tremor and because of the fulcrum effect movement of the instruments outside of the body correspond to movement in the opposite direction inside the body. Furthermore laparoscopy requires ambidexterity, manipulation from a 2-dimensional magnified image on the monitor to 3-dimensional movement inside the abdomen and working with minimal tactile feedback. 
A number of post-graduate laparoscopy courses are available for urologists that did not receive this type of training in residency. Because of the rapidly evolving technology in the field of urology, post-graduate courses are important to allow the practicing urologist to stay current by learning new surgical techniques. The post-graduate courses come in one to two day sessions or longer "mini-fellowships" (5-day course) and usually involve didactic sessions, animal or cadaver laboratories, inanimate model training and case observation or videos. (Table 2.)

\begin{tabular}{|c|c|c|c|c|c|}
\hline Study & $\begin{array}{l}\text { Survey } \\
\text { Resp/Tot } \\
\text { (\% RR) }\end{array}$ & $\begin{array}{l}\text { Course } \\
\text { Description }\end{array}$ & Course Components & $\begin{array}{l}\text { Follow- } \\
\text { Up }\end{array}$ & Results \\
\hline $\begin{array}{l}\text { Kolla et } \\
\text { al., } 2010\end{array}$ & $\begin{array}{l}1 \text { yr: } 77 \% \\
2 \text { yr: } 65 \% \\
3 \text { yr: } 68 \% \\
(\text { Tot }=106)\end{array}$ & $\begin{array}{l}\text { 5-day } \\
\text { laparoscopic } \\
\text { ablative or } \\
\text { laparoscopic } \\
\text { reconstructive } \\
\text { renal surgery } \\
\text { mini- } \\
\text { fellowship }\end{array}$ & $\begin{array}{ll}\text { - } & \text { Tutorial sessions } \\
\text { - } & \text { Inith mentors } \\
\text { - } & \text { skills training } \\
\text { - } & \text { Animal laboratory } \\
\text { skills training } \\
\text { - } & \text { OR observation }\end{array}$ & $\begin{array}{l}\text { Range: } 1 \\
\text { to } 3 \text { years } \\
\text { post- } \\
\text { course }\end{array}$ & \begin{tabular}{|l|} 
5-day mini- \\
fellowship \\
successfully \\
increases case \\
volume and \\
advances the \\
complexity of \\
laparoscopic \\
procedures they \\
perform in \\
practice up to 3 \\
years after the \\
course \\
\end{tabular} \\
\hline $\begin{array}{l}\text { Pareek et } \\
\text { al., } 2008\end{array}$ & $\begin{array}{l}32 / 52 \\
(61 \%)\end{array}$ & $\begin{array}{l}\text { 2-day AUA } \\
\text { Mentored } \\
\text { Laparoscopy } \\
\text { course (2002- } \\
2003)\end{array}$ & 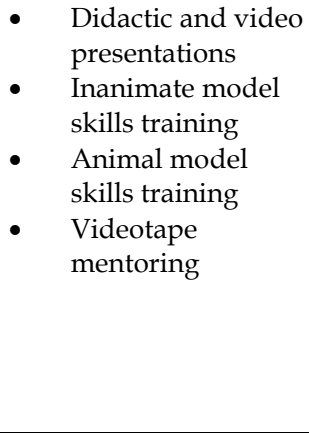 & $\begin{array}{l}\text { Mean: } 48 \\
\text { months } \\
\text { (Range:41 } \\
\text { to 55 } \\
\text { months) }\end{array}$ & 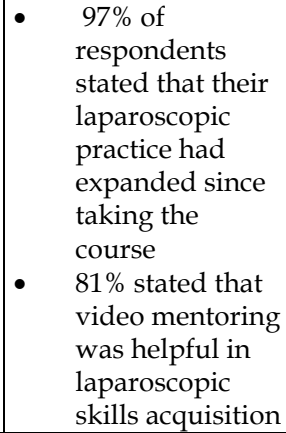 \\
\hline $\begin{array}{l}\text { Marguet } \\
\text { et al., } \\
2004\end{array}$ & $\begin{array}{l}56 / 71 \\
(79 \%)\end{array}$ & $\begin{array}{l}\text { 1-day hand- } \\
\text { assisted } \\
\text { laparoscopy } \\
\text { post-graduate } \\
\text { training course }\end{array}$ & $\begin{array}{ll}- & \text { Didactic } \\
\text { - } & \text { Technique } \\
& \text { Instruction } \\
\text { - } & \text { Animal } \\
& \text { laboratory }\end{array}$ & $\begin{array}{l}\text { Range: } 6 \\
\text { months to } \\
1 \text { year } \\
\text { post- } \\
\text { course }\end{array}$ & $\begin{array}{l}\text { Respondents } \\
\text { who completed } \\
\text { course and } \\
\text { underwent } \\
\text { mentoring by } \\
\text { course instructor } \\
\text { or another } \\
\text { experienced } \\
\text { laparoscopist } \\
\text { were more likely } \\
\text { (93\%) to perform } \\
\text { lap cases than } \\
\text { those who were } \\
\text { not mentored } \\
(44 \%)(\mathrm{p}<0.001)\end{array}$ \\
\hline
\end{tabular}




\begin{tabular}{|c|c|c|c|c|c|}
\hline Study & $\begin{array}{l}\text { Survey } \\
\text { Resp/Tot } \\
(\% \text { RR) }\end{array}$ & $\begin{array}{l}\text { Course } \\
\text { Description }\end{array}$ & Course Components & $\begin{array}{l}\text { Follow- } \\
\text { Up }\end{array}$ & Results \\
\hline $\begin{array}{l}\text { Colegrove } \\
\text { et al., } \\
1999\end{array}$ & $\begin{array}{l}168 / 322 \\
(52 \%)\end{array}$ & $\begin{array}{l}\text { 2-day } \\
\text { university } \\
\text { sponsored } \\
\text { post-graduate } \\
\text { laparoscopic } \\
\text { training course }\end{array}$ & $\begin{array}{ll}\text { - } & \text { Didactic } \\
\text { - } & \text { Live video } \\
& \text { presentations } \\
\text { - } & \text { - Animal model } \\
& \text { skills training } \\
\text { - } & \text { - Laparoscopy } \\
\text { simulator } \\
\text { laboratory }\end{array}$ & $\begin{array}{l}\text { Range: } 4.5 \\
\text { to } 7 \text { years } \\
\text { post- } \\
\text { course }\end{array}$ & $\begin{array}{l}54 \% \text { had } \\
\text { performed } 1 \text { or } \\
\text { more lap } \\
\text { procedures in } \\
\text { past year }(>4.5 \\
\text { yr after course) } \\
\text { compared to } \\
84 \% 1 \text { yr after } \\
\text { taking the } \\
\text { course }\end{array}$ \\
\hline
\end{tabular}

Table 2. Description of Laparoscopy Training Courses and Results of Follow-Up Surveys. Survey Resp/Tot: Number of survey respondents/Total number of urologists taking the course; RR: survey response rate (\%); lap:laparoscopy; yr: year

Rane describes a 9-phase mini-fellowship training model for urologic laparoscopic surgery. (RaneA, 2005) Phase 1 is completion of a basic and advanced training course and an animal laboratory prior to the mini-fellowship. Phase 2 is practice at home or in the office using pelvic trainers with phase 3 proceeding to an animal laboratory course. Phase 4 incorporates visits to centers of international repute to observe high-volume laparoscopic urology followed by observing the mentor perform several major renal laparoscopic cases in phase 5 . the trainee then performs several hand-assisted renal procedures under direct mentor guidance at the mentor hospital in phase 6 with the trainee then advancing to perform laparoscopic or retroperitoneoscopic renal surgeries in phase 7 under the mentor's guidance. In phase 8 the trainee mentors and assists other trainees to start laparoscopic surgery at their own hospitals prior to practicing laparoscopy independently in the final phase. Though this is a very thorough and comprehensive fellowship model and it is reported that 9 trainees have participated in the fellowship over 36 months it is unclear how much time the fellowship takes or if there is any objective data on follow-up or incorporation of laparoscopic skills into their practice.

Pansodoro et al describe a 4 step program consisting of observation, theoretical learning, assisting and operating to teach laparoscopy. Fourteen trainees underwent this training program from 2001 to 2005 . One year after completing the program, 12 out of the 14 trainees were performing laparoscopic urology at their home institution. They reported no major complications and their conversion rate was $<2 \%$.

\subsection{Surgical mentoring}

Mentoring surgeons early in their laparoscopic experience has been shown to shorten the learning curve and lower the complication rates. (Fabrizio et al., 2003) Video mentoring allows an instructor to better critique laparoscopic performance and technique in order to help a course participant better improve the basic skills required for laparoscopy. (Hedican \& Nakada, 2007) Nakada et al showed that expert videotape mentoring and analysis of laparoscopic skills training of urologists during an AUA-sponsored hands-on laparoscopy course can improve laparoscopic skills gained during the course. (Nakada et al., 2004) In a survey of participants of a mentored laparoscopy course, Pareek et al found that $81 \%$ of course respondents felt that videotape mentoring was valuable. (Pareek et al., 2008) 
Marguet et al. showed that mentoring post-graduate urologists for their initial hand-assisted laparoscopic case after taking a hand-assisted laparoscopy course lead to greater integration of laparoscopy into a community based urology practice. (Marguet et al., 2004) A survey was sent to 71 urologists who had taken the hand-assisted laparoscopy course with $53 \%$ of the course participants receiving post-course mentoring. Ninety three percent of the mentored surgeons trained in hand-assisted laparoscopy were performing these operations compared to only $44 \%$ of the non-mentored participants 6 months after the course. Shalhav and colleagues further incorporated the mentoring relationship into their training method. (Shalhav et al., 2002) Participants completed a standard animate and inanimate training course and then entered into mentorship training with their instructor. The training included an observational period where the participant watched a number of procedures at their mentor's hospital followed by the instructor then assisting the trainee in complex laparoscopic operations at the trainee's hospital. Of the two surgeons trained via this method, one performed 30 laparoscopic cases in the first 8 months and the other 10 cases in the first 3 months after completion of the course. Fabrizio et al have also reported that expert mentoring can also be valuable to experienced laparoscopists learning a new complex procedure such as laparoscopic radical prostatectomy. (Fabrizio et al.,2003) Despite the benefits of more rapid skills acquisition from mentorship following completion of a laparoscopic training course, the time commitment required by both the trainee and mentoring surgeon and the need to obtain temporary operating privileges and malpractice coverage at another hospital can both be a significant obstacles to overcome. (Hedican \& Nakada, 2007)

\section{Competency in laparoscopy}

Reports revealing the prevalence of medical errors has prompted calls for closer scrutiny of surgical training and practice. (Hasson HM, 2006; Cushieri A, 1995) The Accreditation Council of Graduate Medical Education (ACGME) has identified six core competencies (patient care, medical knowledge, professionalism, system-based practice, practice-based learning and interpersonal/communication skills) to define competence. (Kavic MS, 2002) These 6 competencies are pertinent to laparoscopic surgeons in their ability to care for their patients. The competencies of patient care and medical knowledge encompass the cognitive and technical skills that are unique to laparoscopy and include: 1.) pre-operative care: diagnosis, pre-operative preparation and medical judgement 2.) operative performance: cognitive and technical skills, intra-operative judgement 3.) post-operative care: monitoring, treatment and medical judgement. (Hasson HM, 2006)

Assessing cognitive skills in laparoscopy requires that the surgeon be able to correctly diagnose the situation, assess patients that would be adequate candidates for laparoscopic surgery, understand the physiology of pneumoperitoneum and entry, be able to diagnose and manage intra-operative and post-operative complications and manage the patient postoperatively. These skills are generally taught via didactic lectures and operative videos and tested with multiple-choice tests or discussion of patient management scenarios. Almost all of the post-graduate laparoscopy courses have some didactic or lecture component to address cognitive skills.

The technical skills required to perform laparoscopic surgery can be more difficult to assess. The skills a surgeon needs to acquire include the ability to operate in a 3-dimensional field using the 2-dimensional image on a video screen, adapt to the restricted space/freedom in 
the abdomen, be comfortable with the limited instrument manipulations due to the fulcrum effect and minimal tactile feedback. Laparoscopic training courses focus on helping a trainee develop these skills via both inanimate skills training as well as via an animal laboratory. Newly developed computer-based simulators constitute a new paradigm in laparoscopic surgery training which allow for more objective measurement of laparoscopic skills.

\section{Surgical simulation}

A simulator is defined as "a device that enables the operator to reproduce or represent under test conditions phenomena likely to occur in actual performance" and thus a surgical simulator describes any model used to represent surgery (from box trainers to cadaveric models to virtual reality models). (Wignall et al., 2008) The different types of simulation can be categorized by the concept of fidelity. Low fidelity simulators such as box trainers are those that do not accurately mimic the surgical environment. Despite the lack of realism in these simulators, low fidelity simulators can be important in teaching basic surgical techniques such as laparoscopic knot tying and tend to be low cost and generally portable. High fidelity simulators are those that are more lifelike and can be used to teach an entire operation. These include animal or cadaveric models as well as newly developed virtual reality simulators.

\subsection{Simulator validation}

In order for a simulator to be used to assess competence, it must be evaluated objectively to determine its reliability and validity. (McDougall EM, 2007) The reliability of a training instrument refers to the reproducibility of the test. A given simulator must be consistent in its subject measurement not just with a single trainee on different occasions but also among different trainees. Validity implies that an instrument appropriately measures what it was intended to measure. Face validity establishes that a test seems reasonable and appropriate and is usually assessed by nonexperts in relation to its realism. Content validity assures that the contents of the test cover the relevant areas of the subject being assessed. Face and content validity are relatively subjective appraisals and objective validity assessments (criterion validity, construct validity) are more challenging and time consuming. Criterion validity correlates the results of a new assessment tool with those of an established tool. Criterion validity is composed of concurrent validity (the extent to which a simulator correlates with the "gold standard") and predictive validity (a measure of if a simulator predicts future performance). Construct validity is established by demonstrating differences in test performance between experts and novices in the measured skill and is considered one of the most valuable assessments of a simulator before it is accepted as a competencyevaluating device. (McDougall EM, 2007) In order to validate a simulator the simulator must accurately predict performance in the operating room, however, because there are few reliable measures of surgical performance this can be difficult to achieve. (Wignall et al., 2008)

\subsection{Pelvic trainer}

The pelvic trainer is one of the simplest methods to acquire preliminary laparoscopic skill. It is easy to use and allows surgeons to gain synchronization of both hands in completing a task. The pelvic trainer allows the surgeon to get acclimated to working in a 3-dimensional space based on a 2-dimensional view and is useful in allowing the surgeon to gain 
experience in knot tying. Several low-cost pelvic trainers (camera-less, mirrored box trainers) are available, they may be useful for simple laparoscopic skills but the absence of a camera may also further decrease the fidelity of the simulator as it would not mimic the external set-up and optics during laparoscopy. (Rassweiler et al., 2007) A number of "homemade recipes" for creating laparoscopic box trainers are available in the literature. Though these are relatively low fidelity trainers, they may be helpful in practicing basic laparoscopic skills (object transfer, cutting, suturing, knot tying). (Chung et al., 2005; Blacker AJR, 2005) Construct validity of pelvic box trainers has been shown by Katz et al, who compared the performance of 44 urologists with different levels of laparoscopic experience (beginners, basic, advanced). A significant difference was found among all of the groups (sensitivity: $71-85 \%$, specificity of 74-88\%) A modification of a closed mechanical simulator is the P.O.P trainer which provides pulsating organ perfusion. (Szinicz et al., 2001) The central artery of porcine organs or organ complexes (aorta) is catheterized and connected to a pump on the trainer. The perfusion medium (red colored tap water) is delivered into the organ by the pump. This system can thus allow a higher fidelity simulator and allow one to practice surgical procedures (nephrectomy, partial nephrectomy, retroperitoneal lymph node dissection) and allow for the management of arterial bleeding. However the cost of the simulator is considerable and literature on validation is still lacking. (Autorino et al., 2010)

\section{Low Fidelity a}

- $\quad$ Mirrored box trainer (no camera)

- Box trainer with camera

- Hybrid trainer (similar to box trainer containing organ/tissue)

- $\quad$ Perfused Organ Pelvic trainer (POP Trainer)

\section{High Fidelity (Biological)}

- Animal Models (Porcine)

- Human Cadaver Model

\section{High Fidelity (Virtual Reality)}

- $\quad$ MIST-VR

- LapSim Laparoscopic Trainer (Surgical Science Ltd, Sweden)

Table 3. Types of Simulators for Laparoscopic Surgery in Urology. a: increasing fidelity in descending order from mirrored box trainer to POP trainer

\subsection{Animal and cadaveric models}

Once a trainee has acquired skill working in inanimate models, an animal model is the next step and will allow the surgeon to work in an environment similar to humans. The porcine model is one of the most commonly used animal models and the trainee can gain confidence in obtaining access and pneumoperitoneum and trocar positioning as well as performing the laparoscopic surgical procedure of choice. The animal model allows the surgeon to use all of the same instruments (bipolar or monopolar cautery, clips, stapling devices, hemostatic agents) that he or she would use during laparoscopic surgery as well as allow for similar risk of complications (vascular injury, bowel injury, splenic or liver injury) without harming a human patient. 
Cadaveric models have also been used to teach laparoscopy. Cadavers offer the advantage of helping the trainee gain a perspective of real macroscopic anatomy of all of the organs and structures. Thus spatial perception of anatomy is improved in this model and allows the surgeon to better understand laparoscopic landmarks. (Katz et al., 2003) However, cadaver models do have a number of disadvantages: 1) they do not bleed and thus no hemostasis is required 2) endoscopic vision during the case is always clear 3) tissues dissection is not comparable to a live human being 4) work on cadavers is potentially dangerous due to the risk of the transmission of hematogenous diseases 5) like the porcine model, the cadaveric model can also be expensive. (Piechaud PT \& Pansadoro A, 2006)

\subsection{Virtual reality simulation}

Virtual reality is a new category of simulation that has arisen due to the technologic advances in graphics and computing. Virtual reality is defined as "an artificial environment which is experienced through sensory stimuli provided by a computer and in which one's actions partially determine what happens in the environment." (Wignall et al., 2008) Though virtual reality simulators are fairly expensive and require maintenance, they offer the opportunity to practice basic skills or entire surgical operations in a virtual environment. For a virtual reality simulator to be realistic and valuable it must correctly reproduce anatomy, preserve anatomical characteristics such as weight and deformability and ideally provide some form of tactile feedback. These characteristics can allow for the simulation of mistakes in the virtual environment such as bleeding or injury to other adjacent organs and thus more realistically provide feedback to the surgeon.

Virtual reality simulators can also enhance the evaluation of a trainee by measuring task performance. The Minimally Invasive Surgical Trainer-Virtual Reality (MIST-VR) was one of the first simulators to automatically record a number of different objective measures such as number of errors, time taken for task completion and economy of path length. (Undre \& Darzi, 2007) The MIST-VR set-up includes a frame with 2 laparoscopic instruments attached to it linked to a computer. The system also allows one to train on simple tasks such as picking and placing objects and suturing prior to performing complete procedures. The MIST trainer was able to distinguish between grades of surgeons (construct validity) and was shown to predict performance in the operating room (predictive validity). (Taffinder et al., 1998; Maithel et al., 2005; Seymour et al., 2002) Seymour et al performed a prospective, randomized, double-blinded study that demonstarated that virtual reality training transfers technical skills to the operating.

The LapSim virtual reality trainer (Surgical Science Ltd.) developed in Sweden is a personal computer-based system with a monitor and a laparoscopic interface set-up that includes 2 instruments and a foot pedal. The software for the system consists of a number of modules that can train a surgeon in basic laparoscopic skills (camera navigation, instrument manipulation: grasping, cutting, clipping, suturing). Construct validity has been demonstrated in several studies for the LapSim trainer. (Duffy et al., 2005; Ericksen et al., 2005) Currently the surgery modules for the LapSim trainer include cholecystectomy, appendectomy and gynecologic module (tubal occlusion, salpingectomy, myoma suturing) but no urologic procedure modules have been developed to date.

\section{Laparoscopic skills assessment and course follow-up}

Despite the literature on laparoscopic training courses and various laparoscopic simulators, more studies need to be performed that objectively measure laparoscopic skill acquisition 
along with long-term follow-up of course participants. Criteria used to demonstrate competency in the past have included the number of procedures performed, time taken to complete a case or evaluation by senior surgeons. (Dent TL, 1991; European Association of Endoscopic Surgeons, 1994) However, these criteria are known to be crude and indirect measures of technical skill or to suffer from the influence of subjectivity or bias. (Aggarwal et al., 2004) With the increasing need to assess surgical performance objectively, dexterity analysis and video-based assessment have begun to be used.

The movement of laparoscopic instruments and the surgeon's hands have both been used to help assess surgical performance. Smith et al connected laparoscopic forceps to sensors to map their position in space and relay the movements to a personal computer. This allowed for calculation fo the instrument's total path length which was then compared to the minimum path length required to complete a task. (Smith et al., 2001) The Imperial College Surgical Assessment Device (ICSAD) has sensors placed on the back of a surgeon's hands and studies have confirmed construct validity of the ICSAD as a surgical assessment device for both simple tasks and for surgical procedures. (Taffinder et al., 1999; Torkington et al., 2001; Smith et al., 2002) Experienced laparoscopic surgeons made significantly fewer movements than occasional laparoscopists who were better than novices in the field. The ICSAD device has also been shown to objectively assess the acquisition of psychomotor skill of trainees attending laparoscopic training courses. (Aggarwal et al., 2004)

Martin et al developed a video-based assessment of operative skill, the Objective Structured Assessment of Technical Skill (OSATS). (Martin et al., 1997) OSATS involves 6 tasks on a bench format with direct observation and assesment on a task-specific checklist, a sevenitem global rating sore and a pass/fail evaluation. Twenty surgeons in training of differing experience level performed equivalent open surgical tasks on the bench format and then on live anesthetized animals. There was excellent correlation between assessment on the bench and live models. Test/retest and inter-rater reliabilities were higher for global scores, making them a more reliable and valid measurement tool. OSATS can be used to help assess concurrent validity if a simulator performance score correlates with the OSATS performance score on an accepted evaluating model. OSATS can thus also be used to assess predictive validity. (McDougall EM, 2007) It should be noted that the OSATS performance score evaluation is time consuming as the assessment of 20 surgical trainees on the OSATS required 48 examiners for 3 hours each. (Martin et al., 1997) To achieve instant and more objective feedback on a surgeon's technical skills, virtual reality simulation may be more useful. Studies to confirm the role of virtual reality simulators as assessment devices have concentrated on the demonstration of construct validity, with experienced surgeons completing the tasks on the MIST-VR significantly faster, with lower rates of error and greater economy of movement scores. (Gallagher et al., 2001)

When assessing the impact of laparoscopy training courses, there is limited long-term data on the incorporation of laparoscopy into clinical practice. Of urologists that had participated in laparoscopic training courses at the University of Iowa in 1991, 84\% of respondents had performed at least 1 laparoscopic case at 1 year follow-up. (See et al., 1994) However, 5 year follow-up for the same group of urologists revealed a decline to $54 \%$. (Colegrove et al., 1999) Pareek et al surveyed urologists taking a mentored laparoscopy course in 2002 and 2003 with a mean follow-up of 48 months found that $97 \%$ of respondents stated that their laparoscopic practice had expanded. (Pareek et al., 2008) Kolla et al surveyed urologists that had completed their 5-day mini-fellowhip in laparoscopic surgery found that $72 \%, 71 \%$ and $71 \%$ of respondents performed laparoscopic renal surgery at 1,2 and 3 years respectively 
since completing the course. (Kolla et al., 2010) Though it appears that there is good incorporation of laparoscopic surgery into clinical practice, more studies with long-term (> 5 years) follow-up are required to better assess the impact of post-graduate courses.

\section{Conclusions}

The exponential rise and incorporation of technology in urology has fueled the need for better post-graduate laparoscopic courses and methods to aid urologists in skill acquisition. Training courses have been shown to help decrease the learning curve associated with laparoscopy and the need has diminished as more and more trainees are fully trained in the technique. More studies with long term follow-up are needed to better assess incorporation of laparoscopy into urologists' clinical practice. Though a number of different simulators are available to help with laparoscopic skill acquisition and even for certification purposes, it is important that simulators undergo thorough validation testing prior to being approved for competency assessment.

\section{References}

Aggarwal R, Moorthy K, Darzi A. (2004). Laparoscopic skills training assesment. British Journal of Surgery, Vol.91, No.12, pp. 1549-1558, ISSN 1365-2168

Aggarwal R, Hance J, Moorthy K, Munz Y, Undre S, Darzi A. (2004). Assessment of psychomotor skills acquisition during laparoscopic cholecystectomy courses. American Journal of Surgery, Vol.190, No.3, pp. 507-511, ISSN 1879-1883

Bergman S, Feldman LS, Anidjar M, Demyttenaere SV, Carli F, Metrakos P, Tchervenkov J, Paraskevas S, Fried GM. (2008). "First, do no harm": monitoring outcomes during the transition from open to laparoscopic live donor nephrectomy in a Canadian centre. Canadian Journal of Surgery, Vol.51, No.2, pp. 103-110, ISSN 1488-2310

Blacker AJ. (2005). How to build your own laparoscopic trainer. Journal of Endourology, Vol.19, No.6, pp. 748-752, ISSN 1557-900X

Caddedu JA, Wolf JS Jr, Nakada SY, Chen R, Shalhav A, Bishoff JT, Hamilton B, Schulam PG, Dunn M, Hoenig D, Fabrizio M, Hedican S, Averch TD. (2001). Complications of laparoscopic procedures after concentrated training in urological laparoscopy. The Journal of Urology, Vol.166, No.6, pp. 2109-2111, ISSN 1527-3792

Chou DS, Abdelshehid CS, Uribe CA, Khonsari SS, Eichel L, Boker JR, Shanberg AM, Ahlering TE, Clayman RV, McDougall EM. (2005). Initial impact of a dedicated postgraduate laparoscopic mini-residency on clinical practice patterns. Journal of Endourology, Vol.19, No.3, pp. 360-365, ISSN 1557-900X

Chung SY, Landsittel D, Chon CH, Ng CS, Fuchs GJ. (2005). Laparoscopic skills training using a webcam trainer. The Journal of Urology, Vol.173, No.1, pp. 180-183, ISSN 1527-3792

Clayman RV, Kavoussi LR, Soper NJ, Dierks SM, Merety KS, Darcy MD, Long SR, Roemer FD, Pingleton ED, Thomson PG. (1991). Laparoscopic nephrectomy. The New England Journal of Medicine, Vol.324, No. 19, pp. 1370-1371, ISSN 1533-4406

Colegrove PM, Winfield HN, Donovan JF, et al. Laparoscopic practice patterns among North American urologists 5 years after formal training. (1999) The Journal of Urology, Vol.161, No.3, pp. 881-886, ISSN 1527-3792 
Corica F, Boker JR, Chou DS, White SM, Abdelshehid CS, Stoliar G, Sala LG, Shanberg AM, Clayman RV, McDougall EM. (2006) Short-term impact of a laparoscopic "miniresidency" experience on postgraduate urologists' practice patterns. Journal of the American College of Surgeons, Vol.203, No.3, pp.692-698, ISSN 1879-190

Cuschieri A. (1995). Whither minimal access surgery:tribulations and expectations. American Journal of Surgery, Vol.169, No.1, pp.9-18, ISSN 1879-1883

Dent TL. (1991). Training, credentialing, and granting of clinical privileges for laparoscopic general surgery. American Journal of Surgery, Vol.161, No.3, pp. 399-403, 1879-1883

Derosis AM, Fried GM, Abrahamowicz M, Sigman HH, Barkun JS, Meakins JL. (1998). Development of a model for training and evaluation of laparoscopic skills. Am American Journal of Surgery, Vol.175, No.6, pp. 482-487, ISSN 1879-1883

Duffy AJ, Hogle NJ, McCarthy H, Lew JI, Egan A, Christos P, Fowler DL. (2005). Construct validity for the LAPSIM laparoscopic surgical simulator. Surgical Endoscopy, Vol.19, No.3, pp. 401-405. ISSN 1432-2218

Emken JL, McDougall EM, Clayman RV. (2004). Training and assessment of laparoscopic skills. Journal of the Society of Laparoendoscopic Surgeons, Vol.8, No.2, pp. 195199, ISSN 1938-3797

Eriksen JR, Grantcharov T. (2005) Objective assessment of laparoscopic skills using a virtual simulator. Surgical Endoscopy, Vol.19, No.9, pp. 1216-1219, ISSN 1432-2218

European Association of Endoscopic Surgeons. (1994). Training and assessment of competence. Surgical Endoscopy, Vol.8, No.6, pp. 721-722, ISSN 1432-2218

Fabrizio MD, Tuerk I, Schellhammer PF. (2003). Laparoscopic radical prostatectomy: decreasing the learning curve using a mentor initiated approach. The Journal of Urology, Vol.169, No.6, pp. 2063-2065, ISSN 1527-3792

Figert PL, Park AE, Witzke DB, Schwartz RW. (2001). Transfer of training in acquiring laparoscopic skills. Journal of the American College of Surgeons, Vol.193, No.5, pp.533537, ISSN 1879-190

Gallagher AG, Richie K, McClure N, McGuigan J. (2001). Objective psychomotor skills assessment of experienced, junior, and novice laparoscopists with virtual reality. World Journal of Surgery, Vol.25, No.11, pp. 1478-1483, ISSN 1432-2323

Gaston KE, Moore DT, Pruthi RS. (2004). Hand-assisted laparoscopic nephrectomy: prospective evaluation of learning curve. The Journal of Urology, Vol.171, No.1, pp. 63-67, ISSN 1527-3792

Gomella LG, Strup SE. The history of urologic laparoscopy: from cystoscope to laparoscope. In Laparoscopic Urologic Surgery, Eds. Gomella LG, Kozminski M, Winfield HN. Raven Press, Ltd., New York (C) 1994; pp 9-14, ISBN 0781700442

Greco EF, Regher G, Okrainec. (2010). Identifying and classifying problem areas in laparoscopic skills acquisition: Can simulators help? Academic Medicine, Vol.85, No.10 Suppl, pp. S5-S8, ISSN 1938-808X

Hasson HM. (2006). Core competency in laparoendoscopic surgery. Journal of the Society of Laparoendoscopic Surgeons, Vol.10, No.1, pp. 16-20, ISSN 1938-3797

Hedican SP, Nakada SY. (2007) Videotape mentoring and surgical simulation in laparoscopic courses. Journal of Endourology, Vol.21, No.3, pp. 288-293, ISSN 1557$900 \mathrm{X}$

Higashihara E, Baba S, Nakagawa K, Murai M, Go H, Takeda M, Takahashi K, Suzuki K, Fujita K, Yoshinari O, Ohshima S, Matsuda T, Terachi T, Yoshida O. (1998). Learning curve and conversion to open surgery in cases of laparoscopic 
adrenalectomy and nephrectomy. The Journal of Urology, Vol.159, No.3, pp.650-653, ISSN 1527-3792

Hollenbeck BK, Seifman BD, Wolf JS Jr. (2004). Clinical skills acquisition for hand-assisted laparoscopic donor nephrectomy. The Journal of Urology, Vol.171, No.1, pp.35-39, ISSN 1527-3792

Hoznek A, Salomon L, de la Taille A, Yiou R, Vordos D, Larre S, Abbou CC. (2006). Simulation training in video-assisted urologic surgery. Current Urology Reports, Vol.171, No.1. pp.107-113, ISSN 1534-6285

Hruza M, Weib HO, Pini G, Goezen AS, Schulze M, Teber D, Rassweiler JJ. (2010). Complications in 2200 consecutive laparoscopic radical prostatectomies: standardized evaluation and analysis of learning curves. European Urology, Vol.58, No.5, pp.733-741, ISSN 1873-7560

Jeon SH, Han K, Yoo KH, Choe BK, Seo IY, Lim JS, Ono Y. (2009). How many cases are necessary to develop competence for laparoscopic radical nephrectomy? Journal of Endourology, Vol.23, No.12, pp.1965-1970, ISSN 1557-900X

Katz R, Hoznek A, Antiphon P, Van Velthoven R, Delmas V, Abbou CC. (2003). Cadaveric versus porcine models in urologic laparoscopic training. Urologia Internationalis, Vol.71, No.3, pp.310-315, 1423-0399

Katz R, Hoznek A, Salomon L, Antiphon P, de la Taille A, Abbou CC. (2005). Skill assessment of urologic surgeons: Can criterion levels of surgical performance be determined using the pelvic box trainer? European Urology, Vol.47, No.4, pp. 47:482-487, ISSN 1873-7560

Kavic MS. (2002). Competency and the six core competencies. JSLS, Vol.6, No.2, pp. 95-97.

Kolla SB, Gamboa AJ, Li R, Santos RT, Gan JM, Shell C, Andrade L, Louie MK, Clayman RV,

McDougall EM. (2010). Impact of a laparoscopic renal surgery mini-fellowship program on postgraduate urologist practice patterns at a 3-year follow-up. The Journal of Urology, Vol.184, No.5, pp.2089-2093, ISSN 1527-3792

Kumar U, Gill IS. (2006). Learning curve in human laparoscopic surgery. Current Urology Reports, Vol.7, No.2, pp. 120-124, ISSN 1534-6285Link RE, Bhayani SB, Allaf ME, Varkarakis I, Inagaki T, Rodgers C, Su L, Jarrett TW,

Kavoussi LR. (2005). Exploring the learning curve, pathological outcomes and perioperative morbidity of laparoscopic partial nephrectomy performed for renal mass. The Journal of Urology, Vol.173, No.5, pp. 1690-1694, ISSN 1527-3792

Laguna MP, de Reijke TM, Wijkstra H, de la Rosette J. (2006). Training in laparoscopic urology. Current Opinion in Urology, Vol.16, No.2, pp.65-70, ISSN 1473-6586

Lynch J, Aughwane P, Hammond TM. (2010). Video games and surgical ability:A literature review. Journal of Surgical Education, Vol.67, No.3, pp. 184-189, 1878-7452

McDougall EM. (2007). Validation of surgical simulators. Journal of Endourology, Vol.21, No.3, pp.244-247, ISSN 1557-900X

Maithel S, Sierra R, Korndorffer J, Neumann P, Dawson S, Callery M, Jones D, Scott D. (2006). Construct and face validity of MIST-VR, Endotower and CELTS: Are we ready for skills assessment using simulators? Surgical Endoscopy, Vol.20, No.1, pp.104-112, ISSN 1432-2218

Marguet CG, Young MD, L'Esperance JO, Tan YH, Ekeruo WO, Preminger GM, Albala DM. (2004). Hand assisted laparoscopic training for postgraduate urologists:The role of mentoring. The Journal of Urology, Vol.172, No.1, pp.286-289, ISSN 1527-3792 
Martin JA, Regehr G, Reznick R, MacRae H, Murnaghan J, Hutchinson C, Brown M. (1997). Objective structured assessment of technical skill (OSATS) for surgical residents. The British Journal of Surgery, Vol.84, No.2, pp. 273-278, ISSN 0007-1323

Munver R, Del Pizzo JJ, Sosa RE. (2004). The advantages of hand-assisted laparoscopy. Current Urology Reports, Vol.5, No.2, pp.100-7, ISSN 1534-6285

Nakada SY, Moon TD, Gist M, Mahvi D. (1997). Use of the pneumo sleeve as an adjunct in laparoscopic nephrectomy. Urology, Vol.49, No.4, pp. 612-613, ISSN 1527-9995

Nakada SY, Hedican SP, Bishoff JT, Shichman SJ, Wolf JS Jr. (2004). Expert videotape analysis and critiquing benefit laparoscopic skills training of urologists. Journal of the Society of Laparoendoscopic Surgeons, Vol.8, No.2, pp.183-186, ISSN 1938-3797

Nelson CP, Wolf JS Jr. (2002). Comparison of hand-assisted versus standard laparoscopic radical nephrectomy for suspected renal cell carcinoma. The Journal of Urology, Vol.167, No.5, pp.1989-1994, ISSN 1527-3792

Pareek G, Hedican SP, Bishoff JT, Shichman SJ, Wolf JS Jr, Nakada SY. (2008). Skills-based laparoscopy training demonstrates long-term transfer of clinical laparoscopic practice:additional follow-up. Urology, No.72, No.2, pp.265-267, ISSN 1527-9995

Phillips J, Catto JW, Lavin V, Doyle D, Smith DJ, Hastie KJ, Oakley NE. (2005). The laparoscopic nephrectomy learning curve: a single centre's development of a de novo practice. Postgraduate Medical Journal, Vol.81, No.959, pp.599-603, ISSN 14690756

Piechaud PT, Pansadoro A. (2006). Transfer of skills from the experimental model to the patients. Current Urology Reports, Vol.7, No.2, pp.96-99, ISSN 1534-6285

Pietrow PK, Auge BK, Terranova S, Ekeruo W, Preminger GM, Albala DM. (2004). Handassisted laparoscopic nephrectomy:the transfer of experience to a new academic center. Journal of Endourology, Vol.18, No.9, pp. 840-843, ISSN 1557-900X

Rane A. (2005). A training module for laparoscopic urology. JSLS, Vol.9, No.4, pp.460-462.

Rassweiler J, Klein J, Teber D, Schulze M, Frede T. (2007). Mechanical simulators for training for laparoscopic surgery in urology. Journal of Endourology, Vol.21, No.3, pp.252-262, ISSN 1557-900X

Ratner LE, Cisek LJ, Moore RG, Cigarroa FG, Kaufman HS, Kavoussi LR. (1995). Laparoscopic live donor nephrectomy. Transplantation, Vol.60, No.9, pp.10471049, ISSN 0041-1337

Rawlins MC, Hefty TL, Brown SL, Biehl TR. (2002). Learning laparoscopic donor nephrectomy safely: a report on 100 cases. Arch Surg, Vol.137, No.5, pp.531-535.

Rosser JC, Lynch PJ, Cuddihy L, Gentile DA, Klonsky J, Merrell R. (2007). The impact of video games on training surgeons in the 21 $1^{\text {st }}$ century. Archives of Surgery, Vol.142, No.2, pp.181-186, ISSN 0272-5533

Scott DJ, Young WN, Tesfay ST, Frawley WH, Rege RV, Jones DB. (2001). Laparoscopic skills training. American Journal of Surgery, Vol.182, No.2, pp.137-142, ISSN 18791883

Secin FP, Savage C, Abbou C, de la Taille A, Saloman L, Rassweiler J, Hruza M, Rozet F, Cathelineaur X, Janetschek G, NAssar F, Turk I, Vanni AJ, Gill IS, Koenig P, Kaouk JH, Pineiro LM, Pansadoro V, Emiliozzi P, Bjartell A, Jiborn T, Eden C, Richards AJ, Van Velthoven R, Stolzenberg J, Rabenalt R, Su L, Pavlovish CP, Levinson AW, Touijer KA, Vikers A, Guillonneau B. (2010). The learning curve for laparoscopic radical prostatectomy: an international multicenter study. The Journal of Urology, Vol.184, No.6, pp.2291-2296, ISSN 1527-3792 
See WA, Cooper CS, Fisher RJ. (1994). Urological laparoscopic practice patterns 1 year after formal training. The Journal of Urology, Vol.151, No.6, pp.1595-1598, ISSN 1527-3792

Seymour NE, Gallagher AB, Roman SA, O'Brien MK, Bansal VK, Andersen DK, Satava RM. (2002). Virtual reality training improves operating room performance:results of a randomized, double-blinded study. Annals of Surgery, Vol.236, No.4, pp.458-463, ISSN 0003-4932

Shalhav AL, Dabagia MD, Wagner TT, Koch MO, Lingeman JE. (2002). Training postgraduate urologists in laparoscopic surgery: the current challenge. The Journal of Urology, Vol.167, No.5, pp.2135-2137, ISSN 1527-3792

Smith CD, Farrell TM, McNatt SS, Metreveli RE. (2001). Assessing laparoscopic manipulative skills. American Journal of Surgery, Vol.181, No.6, pp.547-550, ISSN 1879-1883

Smith SG, Torkington J, Brown TJ, Taffinder NJ, Darzi A. (2002). Motion analysis. Surgical Endoscopy, Vol.16, No.4, pp.640-645, ISSN 1432-2218

Stelzer MK, Abdel MP, Sloan MP, Gould JC. (2009). Dry lab practice leads to improved laparoscopic performance in the operating room. The Journal of Surgical Research, Vol.154, No.1, pp.163-166, ISSN 1095-8673

Szinicz G, Beller S, Bodner W, Zerz A, Szincz S. (2001). Simulated operations by pulsatile organ-perfusion in minimally invasive surgery. Surgical Laparoscopy $\mathcal{E}$ Endoscopy, Vol.15, No.4, pp. 232-241, ISSN 1051-7200

Taffinder NJ, Smith SG, Mair J, Russell RC, Darzi A. (1999). Can a computer measure surgical precision? Reliability, validity and feasibility of the ICSAD. Surgical Endoscopy, Vol.13, No.Suppl 1, pp.S81, ISSN 1432-2218

Taffinder N, Sutton C, Fishwick RJ, McManus IC, Darzi A. (1998). Validation of virtual reality to teach and assess psychomotor skills in laparoscopic surgery: results from randomized controlled studies using the MIST VR laparoscopic simulator. Studies in Health Technology and Informatics, Vol.50, pp.124-130, ISSN 0926-9630

Thijssen AS, Schijven MP. (2010). Contemporary virtual reality laparoscopy simulators: quicksand or solid grounds for assessing surgical trainees? American Journal of Surgery, Vol.199, No.4, pp.529-541, ISSN 1879-1883

Torkington J, Smith SG, Rees BI, Darzi A. (2001). Skill transfer from virtual reality to a real laparoscopic task. Surgical Endoscopy, Vol.15, No.10, pp.1076-1079, ISSN 1432-2218

Undre S, Darzi A. (2007). Laparoscopy simulators. J Endourol, Vol.21, No.3, pp.274-279.

Vlaovic PD, Sargent ER, Boker JR, Corica FA, Chou DS, Abdelshehid CS, White SM, Sala LG, Chu F, Le T, Clayman RV, McDougall EM. (2008). Immediate impact of an intensive one-week laparoscopy training program on laparoscopic skills among postgraduate urologists. Journal of the Society of Laparoendoscopic Surgeons, Vol.12, No.1, pp.1-8, ISSN 1938-3797

Wignall GR, Denstedt JD, Preminger GM, Cadeddu JA, Pearle MS, Sweet RM, McDougall EM. (2008). Surgical simulation: A urological perspective. The Journal of Urology, Vol.179, No.5, pp.1690-1699, ISSN 1527-3792 


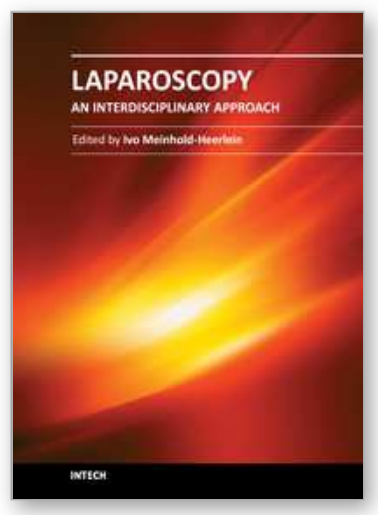

\section{Laparoscopy - An Interdisciplinary Approach}

Edited by Dr. Ivo Meinhold-Heerlein

ISBN 978-953-307-299-9

Hard cover, 146 pages

Publisher InTech

Published online 12, September, 2011

Published in print edition September, 2011

Over the last decades an enormous amount of technical advances was achieved in the field of laparoscopy. Many surgeons with surgical, urological, or gynaecological background have contributed to the improvement of this surgical approach which today has an important and fixed place in the daily routine. It is therefore comprehensible to compose a book entitled laparoscopy serving as a reference book for all three disciplines. Experts of each field have written informative chapters which give practical information about certain procedures, indication of surgery, complications and postoperative outcome. Wherever necessary, the appropriate chapter is illustrated by drawings or photographs. This book is advisable for both beginner and advanced surgeon and should find its place in the libraries of all specialties â€" surgery, urology, and gynecology.

\section{How to reference}

In order to correctly reference this scholarly work, feel free to copy and paste the following:

Sutchin R Patel and Stephen Y Nakada (2011). Laparoscopy Training Courses in Urology, Laparoscopy - An Interdisciplinary Approach, Dr. Ivo Meinhold-Heerlein (Ed.), ISBN: 978-953-307-299-9, InTech, Available from: http://www.intechopen.com/books/laparoscopy-an-interdisciplinary-approach/laparoscopy-training-courses-inurology

\section{INTECH}

open science | open minds

\author{
InTech Europe \\ University Campus STeP Ri \\ Slavka Krautzeka 83/A \\ 51000 Rijeka, Croatia \\ Phone: +385 (51) 770447 \\ Fax: +385 (51) 686166 \\ www.intechopen.com
}

\author{
InTech China \\ Unit 405, Office Block, Hotel Equatorial Shanghai \\ No.65, Yan An Road (West), Shanghai, 200040, China \\ 中国上海市延安西路65号上海国际贵都大饭店办公楼 405 单元 \\ Phone: +86-21-62489820 \\ Fax: +86-21-62489821
}


(C) 2011 The Author(s). Licensee IntechOpen. This chapter is distributed under the terms of the Creative Commons Attribution-NonCommercialShareAlike-3.0 License, which permits use, distribution and reproduction for non-commercial purposes, provided the original is properly cited and derivative works building on this content are distributed under the same license. 